\title{
Bacterial and fungal communities in the rhizosphere of field-grown genetically modified pine trees (Pinus radiata D.)
}

\author{
Jana LOTTMANN ${ }^{1 *}$, Maureen O’CALLAGHAN ${ }^{1}$, David BAIRD ${ }^{2}$ and Christian WALTER ${ }^{3}$ \\ 1 AgResearch Limited, Biocontrol and Biosecurity Section, Private Bag 4749, Christchurch 8140, New Zealand \\ 2 VSN (NZ) Limited, 40 McMahon Drive, Christchurch, New Zealand \\ ${ }^{3}$ Scion - Next Generation Biomaterials, Te Papa Tipu Innovation Park, Private Bag 3020, Rotorua, New Zealand
}

This study assessed the impact of Pinus radiata (D. Don) genetically modified (GM) by biolistic insertion of the LEAFY and nptll genes on rhizosphere microbial communities of field grown trees. Rhizosphere soil was sampled quarterly for two consecutive years. A culture-independent approach was used to characterise the microbial communities based on PCR and denaturing gradient gel electrophoresis (DGGE) of 16S/18S rDNA gene fragments, and internal transcribed spacer (ITS) fragments amplified from total rhizosphere DNA. Trees from two independent transformation events were sampled, together with non-modified control trees of the same parental genotype. DGGE profiles of rhizosphere general Bacteria did not differ between GM and control trees with one exception (summer 2006 sample). For Alphaproteo- and Actinobacteria, significant differences between treatments were detected in one out of eight samplings. Small seasonal shifts could be detected in all bacterial communities. General fungal and ectomycorrhizal communities did not differ significantly between GM and control trees with the exception of summer 2006, when ectomycorrhizal communities associated with GM trees from one transformation event differed from those associated with control trees. Small seasonal shifts of general fungal and ectomycorrhizal communities were seen over the two-year sampling period. More detailed analysis of microbial communities at one sampling date (using amplified rDNA restriction analysis (ARDRA) and 16S/18S rDNA sequencing) revealed significant differences in four ARDRA groups between one GM treatment and the control (bacteria), and significant differences in one ARDRA group between the two GM treatments (fungi). When data from all sampling dates are considered together, the low incidence of statistical differences in the microbial communities associated with the genetically modified and control trees suggests that there was no significant impact of this genetic modification on rhizosphere microbial communities.

Keywords: Bacterial and fungal communities / ectomycorrhizal fungi / DGGE / ARDRA / diversity / genetic engineering (GE) / transgenic trees / biosafety

\section{INTRODUCTION}

Advances in technology for genetic transformation have accelerated the development of genetically modified (GM) trees in the last 15 years. More than 30 species of transformed forest trees have been successfully regenerated, amongst them several commercially important conifers, poplars and eucalypts (Henderson and Walter, 2006; van Frankenhuyzen and Beardmore, 2004). Major target traits include herbicide tolerance, pest resistance, abiotic stress tolerance, modified fibre quality and quantity, and altered growth and reproductive development (Bishop-Hurley et al., 2001; Grace et al., 2005; Wagner et al., 2007). Global commercialisation of GM agricultural crops has intensified the public debate around risks and benefits of genetic engineering. Although GM trees do not evoke immediate health concerns, the prospect

*Corresponding author: jana.monk@agresearch.co.nz of their commercialisation is raising concerns regarding potential ecological impacts (Valenzuela et al., 2006; Walter, 2004). The debate around risks of GM trees focuses on several issues, including the possibility that the transgene could spread via vertical or horizontal gene transfer. More economically motivated concerns include the potential instability of gene expression and possible negative effects on tree fitness which could lead to reduced resilience against pathogens or other environmental challenges. As with transgenic agricultural crops, there is also concern that GM trees may impact on soil ecosystem biota and functions, in particular because trees will grow for many years in one location, unlike shortlived annual crops.

Methodological advances in microbial ecology, especially molecular techniques, have facilitated detailed research on the impact of a range of GM plants on soil microbial community structure and function. Effects 
Table 1. Hotelling $T^{2}$ probabilities of sampling times with significant differences in DGGE pattern. Treatments A, B = genetically modified, treatment $\mathrm{C}=$ controls.

\begin{tabular}{lcccc}
\hline DGGE pattern & Season (sampling time) & Treatment & A & B \\
\hline Bacteria & Summer 2006 (8) & B & $\mathbf{0 . 0 3 8 0}$ & - \\
Alphaproteobacteria & Winter 2005 (2) & C & $\mathbf{0 . 0 0 0 9}$ & $\mathbf{0 . 0 4 5 5}$ \\
& & B & 0.5115 & - \\
Actinobacteria & Autumn 2005 (1) & C & 0.0964 & $\mathbf{0 . 0 1 7 0}$ \\
& & B & $\mathbf{0 . 0 2 2 8}$ & - \\
Ectomycorrhiza & Summer 2006 (8) & C & 0.3838 & 0.3118 \\
& & B & 0.1128 & - \\
& & C & $\mathbf{0 . 0 4 5 7}$ & 0.9572 \\
\hline
\end{tabular}

detected to date have been minor when compared with common sources of variation such as agricultural practices, season, plant developmental stage, soil type or plant genotype (Batista et al., 2008; Dunfield and Germida, 2001, 2004; Gyamfi et al., 2002; Heuer et al., 2002; Lottmann et al., 1999; Lukow et al., 2000). Rootassociated bacteria and fungi form close associations with tree roots and are the primary consumers of exudates and other plant-derived materials, so are the most likely group of non-target soil organisms to respond to any changes in plant activity and metabolism that result from genetic modification processes. Different tree species have been shown to harbour different microbial communities (Priha et al., 2001) but to date there has been only very limited research carried out of the impact of transgenic trees on microbial communities, despite more than $700 \mathrm{GM}$ tree field trials that we have been able to find in publicly available databases.

The enormous biological complexity in soils demands that impact studies on soil ecosystems focus on specific and relevant microbial groups. Ectomycorrhizal (EM) fungi play a fundamental role in forest ecosystem processes, by influencing the uptake of minerals and carbon cycling, and alleviating stress to their associated hosts. For many trees it is clear that normal growth and survival is dependent on colonisation by EM fungi (Smith and Read, 1997). Kaldorf et al. (2002) conducted the first field study of mycorrhization of rolC-transgenic (modifies phytohormone balance) aspen trees in a four-year trial. Mycorrhizal colonisation, diversity and community structure did not differ between GM and control trees.

Monterey or radiata pine (Pinus radiata D. Don) is well known as a conifer species deployed in forest plantations, predominantly in New Zealand, Australia, Chile and Spain. The introduced $L E A F Y(L F Y)$ gene from Arabidopsis thaliana is involved in the control of floral development. This was the first time that this gene had been introduced to conifers and given that $L E A F Y$ originates from an angiosperm and was introduced into a gymnosperm, it was not known whether the gene would be expressed, and for how long. The objective of this study was to characterise the structure of the bacterial, fungal and ectomycorrhizal communities associated with the roots of GM and unmodified field grown $P$. radiata over several seasons and to provide baseline data for future biosafety evaluations of a range of GM radiata pine currently under development in New Zealand. General bacterial, fungal and taxon-specific primers were used to PCR-amplify $16 \mathrm{~S} / 18 \mathrm{~S}$ rRNA gene fragments and ITS fragments from community DNA followed by denaturing gradient gel electrophoresis (DGGE). To investigate the diversity of rhizosphere communities, clone libraries of the partial 16S rDNA (bacteria) and the partial 18S rDNA (fungi) were generated from whole community DNA. Clones were characterized by Amplified rDNA Restriction Analysis (ARDRA) and sequencing.

\section{RESULTS}

\section{Rhizosphere bacterial community structure}

DNA was successfully extracted from all 120 rhizosphere soil samples. Prior to bacterial community fingerprinting, the $16 \mathrm{~S}$ rRNA gene fragments were amplified by PCR from whole community DNA with primers specific for general Bacteria, Alpha- and Betaproteobacteria, and Actinobacteria. DGGE profiles of general bacterial communities showed complex fingerprints composed of large numbers of bands with trees sharing many common bands. Consistent bands specific to GM or control trees were not observed but over the whole sampling period of two years, all trees showed minor temporal variations in their DGGE patterns. The principle coordinate analysis (PCO) of DGGE banding patterns for general Bacteria indicated that only at the last of eight sampling times (summer 2006) were significant differences found between GM and non-modified trees (Tab. 1, Fig. 1). Note that, as there were so few sampling dates in the study when significant differences between microbial communities were observed, only Hotelling $T^{2}$ probabilities, where there was a significant difference, are presented 


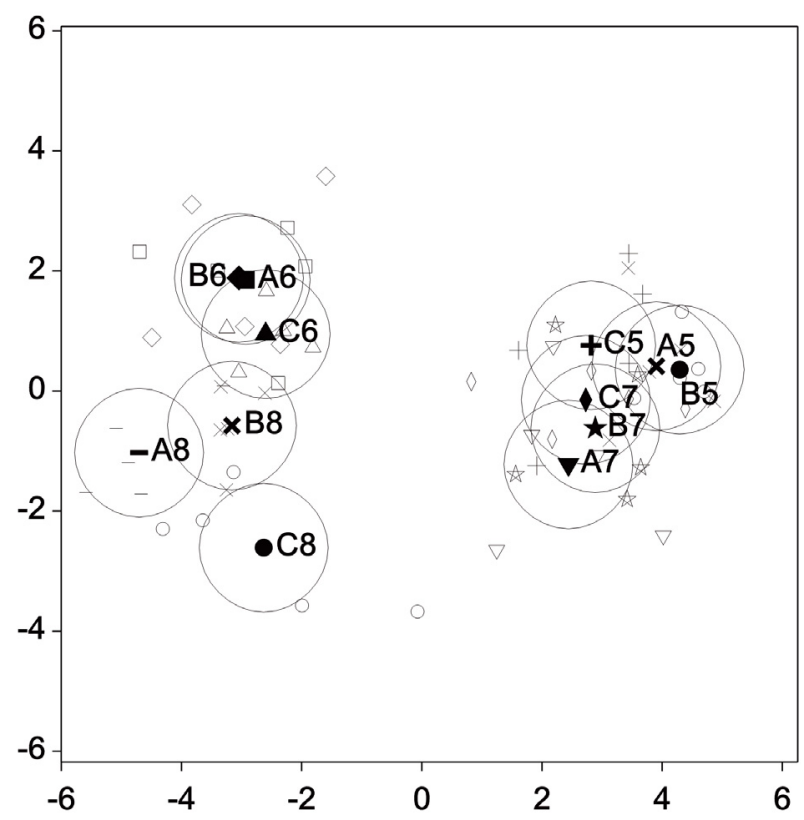

Figure 1. Principle coordinate analysis of bacterial DGGE profiles in 2006. The fingerprints were generated by separation of 16S rDNA fragments amplified with primers F968/R1378. A = GM treatment $\mathrm{A}, \mathrm{B}=\mathrm{GM}$ treatment $\mathrm{B}, \mathrm{C}=$ control. Arabic numerals refer to sampling times: $5=$ autumn 2006, $6=$ winter $2006,7=$ spring 2006, $8=$ summer 2006. Significance of difference between treatments should be read from Table 1 .

in Table 1. Significant seasonal shifts in bacterial communities were found over the two-year sampling period $(P<0.05)$ and were clearly visible for 2006 in Figure 1.

To reduce the complexity of bacterial fingerprints and to allow the analysis of minority populations, primers specific for three taxonomic groups were applied. The fingerprints of Alphaproteobacteria were similar for all trees but showed significant differences between the GM treatment B and the non-GM controls at one of the eight sampling times (winter 2005, Fig. 2, Tab. 1). DGGE profiles of Betaproteobacteria showed no differences between the three treatments but significant seasonal differences in both years $(P<0.05)$. Actinobacterial communities showed significant differences between the two GM treatments A and B at the first sampling time (autumn 2005) but at all other sampling times there were no differences between the three treatments (Fig. 3, Tab. 1). Significant seasonal effects were detected in both years $(P<0.05)$. Figure 4 shows the DGGE patterns of Alphaproteobacteria, Betaproteobacteria and Actinobacteria in 2006 and demonstrates the high similarity of bacterial communities between GM and control trees and minor seasonal changes.

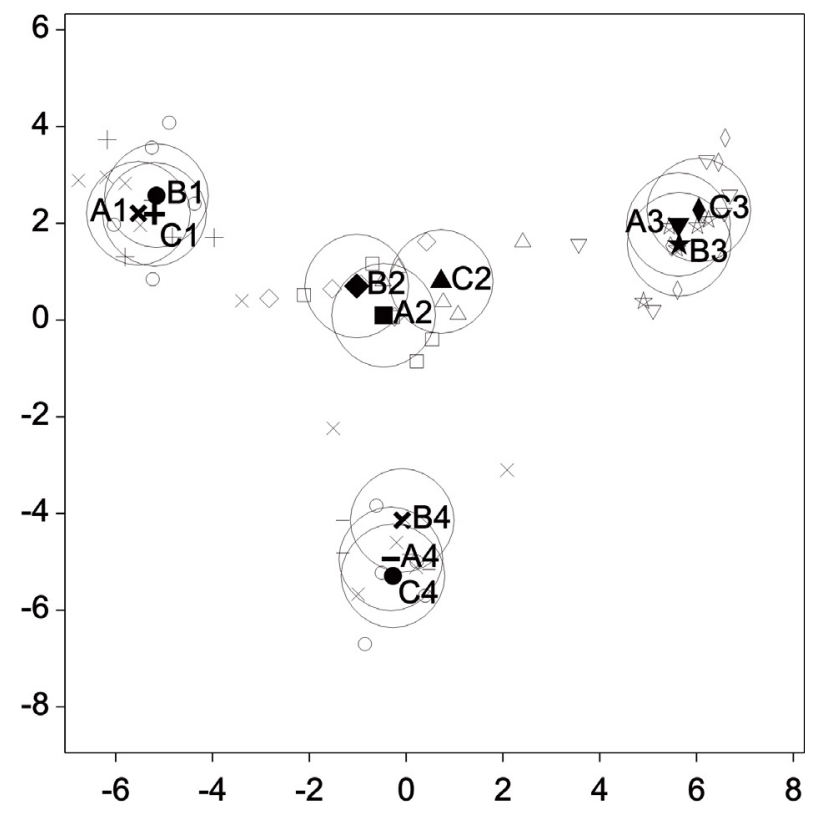

Figure 2. Principle coordinate analysis of alphaproteobacterial DGGE profiles in 2005. A, B = GM treatments, $\mathrm{C}=$ control. Arabic numerals refer to sampling times: $1=$ autumn 2005, $2=$ winter 2005, 3 = spring 2005, $4=$ summer 2005. Significance of difference between treatments should be read from Table 1 .

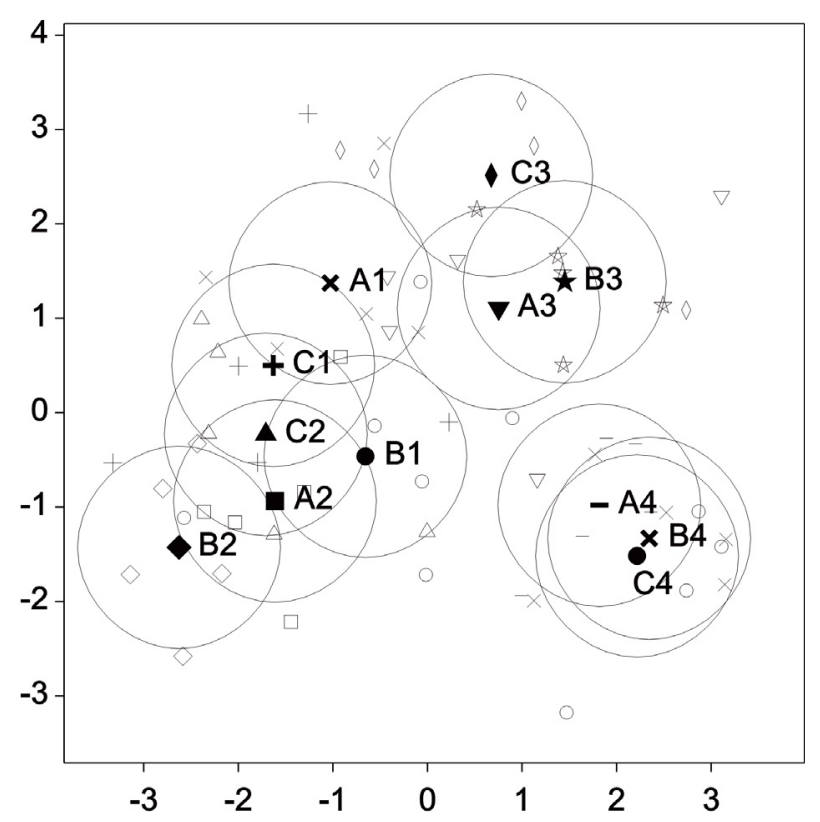

Figure 3. Principle coordinate analysis of actinobacterial DGGE profiles in 2005. A, B = GM treatments, $\mathrm{C}=$ control. Arabic numerals refer to sampling times: $1=$ autumn 2005, $2=$ winter 2005, $3=$ spring 2005, $4=$ summer 2005. Significance of difference between treatments should be read from Table 1. 


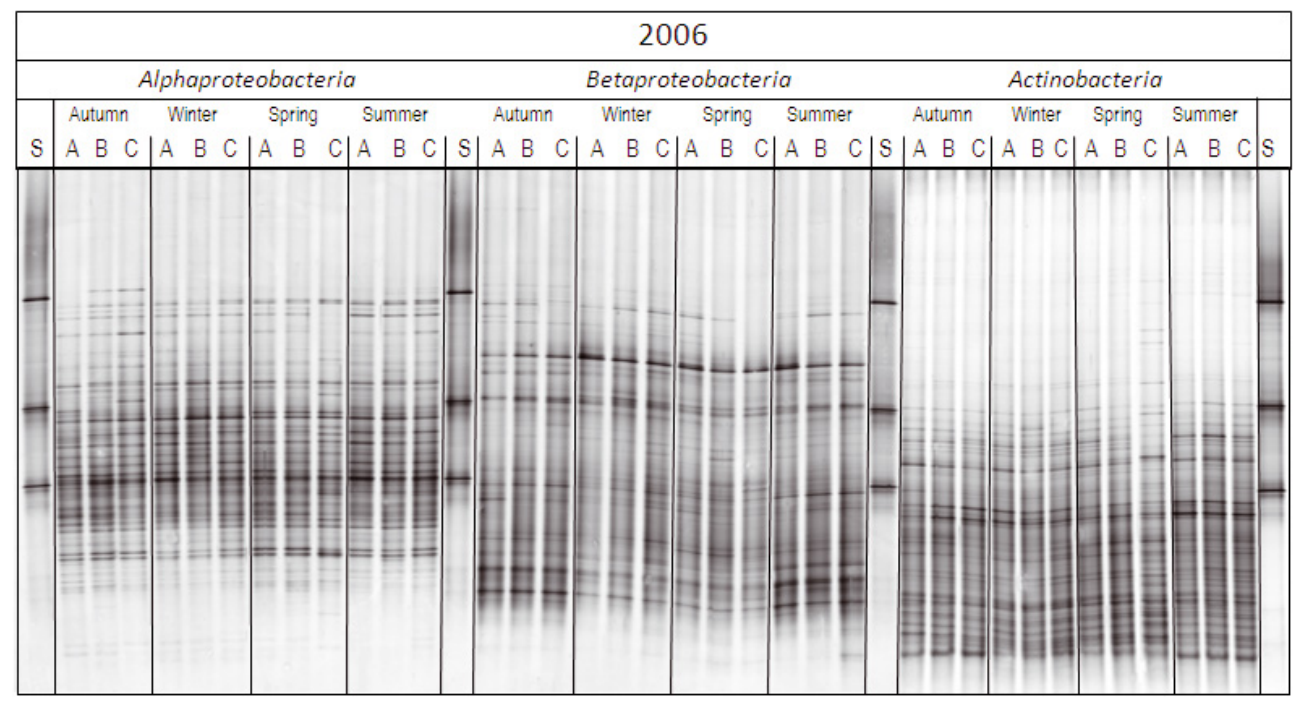

Figure 4. DGGE profiles representing the bacterial communities (Alpha-, Betaproteobacteria, Actinobacteria) of pooled samples of transgenic trees in 2006. A $=5 \times$ GM treatment A, B $=5 \times$ GM treatment B, and C $=5 \times$ control treatment. The fingerprints of bacterial communities were generated by separation of 16S rDNA fragments amplified with taxon-specific primers (Tab. 2) followed by a second PCR using primers F968-GC and R1378. The following bacterial isolates, from top to bottom, were used as standards (lanes S): Pectobacterium carotovorum, Variovorax paradoxus, and Arthrobacter sp.

\section{Rhizosphere fungal community structure}

The complexity of general fungal communities varied between individual trees, although some bands were present in all treatments and some were detected at certain time points in particular treatments. None of the differences were consistent throughout the two-year sampling period or greater than the variability between the seasons. Discriminant analysis showed significant seasonal shifts $(P<0.05)$ but the fungal communities did not differ significantly between GM and control trees (data not shown).

Specific ITS sequences, representing ectomycorrhizal fungi, were amplified by application of the primers ITS1F and ITS4B-GC (Tab. 2). The DGGE profiles revealed 2 to 7 bands per tree with some variation between individual trees. Only at the last sampling time (summer 2006) did the discriminant analysis reveal significant differences between the GM treatment A and non-transgenic controls (Fig. 5, Tab. 1) Significant seasonal shifts were detected in both years but were more pronounced in 2006. Characteristic bands were excised from DGGE gels and after re-amplification the ITS fragments were cloned and sequenced. The sequences of all bands were associated with ectomycorrhizal fungi such as Polyporus tuberaster $(99 \%$ similarity), an uncultured ectomycorrhiza Cantharellales (98\%), an uncultured Tremellales (98\%), an uncultured Clavulina (97\%) and an uncultured Suillacea (99\%).

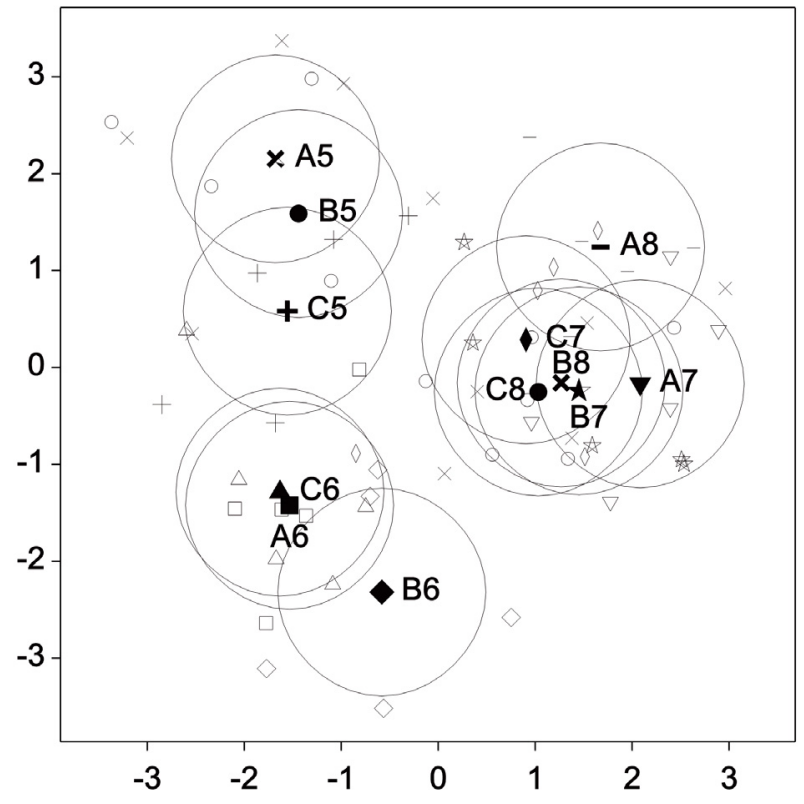

Figure 5. Principle coordinate analysis of ectomycorrhizal DGGE profiles in 2006. The fingerprints were generated by separation of the ITS region amplified with primers ITS1F/ITS4BGC. $A, B=G M$ treatments, $C=$ control. Arabic numerals refer to sampling times: $5=$ autumn 2006, $6=$ winter 2006, $7=$ spring 2006, $8=$ summer 2006. Significance of difference between treatments should be read from Table 1 . 
Table 2. Primers used in this study targeting the 16S, 18S rRNA genes and ITS genes.

\begin{tabular}{|c|c|c|c|}
\hline Primer & Sequence 5'-3' & $\begin{array}{l}\text { Target region/ } \\
\text { Specificity }\end{array}$ & Reference \\
\hline F27 & AGAGTTTGATCCTGGCTCAG & $\begin{array}{l}\text { 16S rRNA gene, } \\
\text { Bacteria }\end{array}$ & Lane (1991) \\
\hline F968 & AACGCGAAGAACCTTAC & $\begin{array}{l}\text { 16S rRNA gene, } \\
\text { Bacteria }\end{array}$ & Nübel et al. (1996) \\
\hline F968-GC & gc-AACGCGAAGAACCTTAC & $\begin{array}{l}\text { 16S rRNA gene, } \\
\text { Bacteria }\end{array}$ & Nübel et al. (1996) \\
\hline $\mathrm{F} 203 \alpha$ & $\begin{array}{l}\text { CCGCATACGCCCTACGGG } \\
\text { GGAAAGATTTAT }\end{array}$ & $\begin{array}{l}\text { 16S rRNA gene, } \\
\text { Alphaproteobacteria }\end{array}$ & Gomes et al. (2001) \\
\hline F948 $\beta$ & CGCACAAGCGGTGGATGA & $\begin{array}{l}\text { 16S rRNA gene, } \\
\text { Betaproteobacteria }\end{array}$ & Gomes et al. (2001) \\
\hline F243HGC & GGATGAGCCCGCGGCCTA & $\begin{array}{l}\text { 16S rRNA gene, } \\
\text { Actinobacteria }\end{array}$ & Heuer et al. (1997) \\
\hline R1378 & CGGTGTGTACAAGGCCC GGGAACG & $\begin{array}{l}\text { 16S rRNA gene, } \\
\text { Bacteria }\end{array}$ & Heuer et al. (1997) \\
\hline R1494 & CTACGGRTACCTTGTTACGAC & $\begin{array}{l}\text { 16S rRNA gene, } \\
\text { Bacteria }\end{array}$ & Weisburg et al. (1991) \\
\hline NS1 & GTAGTCATATGCTTGTCTC & $\begin{array}{l}\text { 18S rRNA gene, } \\
\text { Fungi }\end{array}$ & White et al. (1990) \\
\hline FR1 & AICCATTCAATCGGTAIT & $\begin{array}{l}\text { 18S rRNA gene, } \\
\text { Fungi }\end{array}$ & Vainio and Hantula (2000) \\
\hline FR1-GC & gc-AICCATTCAATCGGTAIT & $\begin{array}{l}\text { 18S rRNA gene, } \\
\text { Fungi }\end{array}$ & Vainio and Hantula (2000) \\
\hline ITS1-F & CTTGGTCATTTAGAGGAAGTAA & $\begin{array}{l}\text { ITS region, } \\
\text { Fungi }\end{array}$ & Gardes and Bruns (1993) \\
\hline ITS4B & CAGGAGACTTGTACACGGTCCAG & $\begin{array}{l}\text { ITS region, } \\
\text { Basidiomycetes }\end{array}$ & Gardes and Bruns (1993) \\
\hline ITS4B-GC & gc-CAGGAGACTTGTACACGGTCCAG & $\begin{array}{l}\text { ITS region, } \\
\text { Basidiomycetes }\end{array}$ & Landeweert et al. (2005) \\
\hline GC-clamp (gc) & $\begin{array}{l}\text { CGCCCGGGGCGCGCCCCGGGCG } \\
\text { GGGCGGGGGCACGGGGGG }\end{array}$ & - & Nübel et al. (1996) \\
\hline
\end{tabular}

These genera all belong to the phylum Basidiomycota and are all well known as ectomycorrhizal fungi of conifers.

\section{Diversity of bacterial and fungal communities}

Nearly full-length bacterial $16 \mathrm{~S}$ rDNA genes were amplified with primers F27/R1494 from community DNA from the summer sampling 2005 and used to generate a random clone library. For each of the three treatments more than 100 clones were randomly selected and checked for the correct insert. Prior to sequencing, ARDRA was used to characterise all clones. The restriction enzyme Hinf I was used to carry out ARDRA on 320 cloned 16S rRNA gene fragments. Data analysis using GelComparII software (Applied Maths, Belgium) revealed 130 HinfI patterns. Each different restriction pattern was defined as an operational taxonomic unit (OTU). Seventy-six OTUs were recovered only once. The GM treatment B yielded 29 , the control treatment 27 , and the GM treatment A
20 unique OTUs. The statistical analysis of OTUs revealed significant differences only between the controls and GM treatment A for OTU2, OTU3, OTU4 and OTU8 with $P$-values of $0.0315,0.0207,0.0345$ and 0.0341 , respectively.

Based on the OTUs, the diversity indices according to Shannon and Weaver (1949) were calculated. The overall diversity was 4.44 . The highest diversity for bacterial clones was found for the GM treatment B (4.05) whereas the diversity indices for controls and GM treatment A were 3.94 and 3.83, respectively. Inserts from each OTU with at least three clones were selected for sequence analysis. A total of 92 clones were sequenced. The results of the sequence analysis are shown in Table 3 . The most frequently represented groups detected in all treatments were members of the Proteobacteria. Betaand Alphaproteobacteria had the greatest representation followed by Bacilli. Nineteen clones grouped into OTU1 and were affiliated with the genus Burkholderia. Figure 6 shows the proportional occurrence of the most frequently 
Table 3. BLAST search results of nucleotide-nucleotide comparison in GenBank and most frequent OTUs associated with the three treatments: non-modified controls (C), and two GM treatments (A and B).

\begin{tabular}{|c|c|c|c|c|c|c|c|c|c|}
\hline \multirow{2}{*}{$\begin{array}{l}\text { Most frequent } \\
\text { OTUs }{ }^{1}\end{array}$} & \multicolumn{4}{|c|}{$\begin{array}{c}\text { Number of occurrence } \\
\text { among treatments }\end{array}$} & \multicolumn{3}{|c|}{ GenBank BLAST analysis } & \multicolumn{2}{|c|}{ Accession no. of clones ${ }^{2}$} \\
\hline & Total & $\mathrm{C}$ & $\mathrm{A}$ & $\mathrm{B}$ & Species $^{\text {Class }}$ & Accession no. & Identity [\%] & Clone & Accession no. \\
\hline \multirow[t]{3}{*}{ OTU1 } & 19 & 9 & 2 & 8 & Burkholderia phenazinium ${ }^{3}$ & AM502992 & 99 & CB73 & FM206295 \\
\hline & & & & & Burkholderia phytofirmans ${ }^{3}$ & CP001053 & 99 & $2 \mathrm{~B} 25$ & FM206296 \\
\hline & & & & & Burkholderia sedimenticola ${ }^{3}$ & EU035613 & 98 & 2B91 & FM206297 \\
\hline \multirow[t]{3}{*}{ OTU2 } & 18 & 6 & 10 & 2 & Uncultured bacterium & EF516003 & 94 & $1 \mathrm{~B} 83$ & FM206298 \\
\hline & & & & & Uncultured bacterium & EU335246 & 98 & CB52 & FM206299 \\
\hline & & & & & Alicyclobacillus sp. ${ }^{4}$ & AB060164 & 96 & $1 \mathrm{~B} 29$ & FM206300 \\
\hline \multirow[t]{3}{*}{ OTU3 } & 10 & 1 & 5 & 4 & Bradyrhizobium japonicum ${ }^{5}$ & EU481826 & 97 & $2 \mathrm{~B} 22$ & FM206301 \\
\hline & & & & & Bacterium Ellin $332^{5}$ & AF498714 & 92 & $1 \mathrm{~B} 82$ & FM206302 \\
\hline & & & & & Devosia sp. $^{5}$ & EF540511 & 91 & 1B112 & FM206303 \\
\hline \multirow[t]{2}{*}{ OTU4 } & 10 & 2 & 5 & 3 & Collimonas fungivorans ${ }^{3}$ & AY593480 & 98 & $\mathrm{CB} 27$ & FM206304 \\
\hline & & & & & Zoogloea ramigera ${ }^{3}$ & X74914 & 92 & $1 \mathrm{~B} 10$ & FM206305 \\
\hline \multirow[t]{2}{*}{ OTU5 } & 10 & 4 & 2 & 4 & Burkholderia sp. ${ }^{3}$ & AF247494 & 99 & $2 \mathrm{~B} 57$ & FM206306 \\
\hline & & & & & Burkholderia phenazinium ${ }^{3}$ & AY154372 & 99 & CB30 & FM206307 \\
\hline \multirow[t]{2}{*}{ OTU6 } & 8 & 2 & 3 & 3 & Mycobacterium colombiense ${ }^{6}$ & AM062764 & 99 & $2 \mathrm{~B} 60$ & FM206308 \\
\hline & & & & & Mycobacterium riyadhense ${ }^{6}$ & EU274642 & 99 & CB36 & FM206309 \\
\hline OTU7 & 7 & 4 & 1 & 2 & Mucilaginibacter paludis ${ }^{7}$ & AM490402 & 93 & CB76 & FM206310 \\
\hline OTU8 & 7 & 1 & 4 & 2 & Labrys monachus ${ }^{5}$ & AJ535707 & 99 & $2 \mathrm{~B} 26$ & FM206311 \\
\hline OTU9 & 7 & 4 & 3 & 0 & Uncultured bacterium WD229 & AJ292593 & 98 & 1B77 & FM206312 \\
\hline OTU10 & 6 & 1 & 2 & 3 & Sphingoterrabacterium koreensis ${ }^{7}$ & AB267721 & 91 & 1B103 & FM206313 \\
\hline OTU11 & 5 & 1 & 2 & 2 & Acidocella sp. ${ }^{5}$ & AF376021 & 96 & 2B18 & FM206314 \\
\hline OTU12 & 5 & 2 & 2 & 1 & Burkholderia sedimenticola ${ }^{3}$ & EU035613 & 99 & 1B6 & FM206315 \\
\hline OTU13 & 5 & 1 & 2 & 2 & 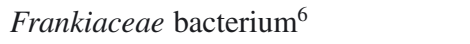 & DQ490442 & 97 & 1B12 & FM206316 \\
\hline OTU14 & 5 & 1 & 3 & 1 & Methylobacterium sp. ${ }^{5}$ & AM910535 & 100 & 1B113 & FM206317 \\
\hline OTU15 & 4 & 2 & 1 & 1 & Sphingomonas sp. K101 ${ }^{5}$ & AJ009706 & 98 & CB101 & FM206318 \\
\hline OTU16 & 4 & 1 & 2 & 1 & Sphingomonas sp. EC-K085 5 & AB264174 & 92 & $1 \mathrm{~B} 97$ & FM206319 \\
\hline OTU17 & 4 & 2 & 2 & 0 & Serratia proteamaculans ${ }^{8}$ & CP000826 & 99 & CB113 & FM206320 \\
\hline OTU18 & 4 & 2 & 0 & 2 & Methylocystis sp. ${ }^{5}$ & DQ852350 & 92 & CB29 & FM206321 \\
\hline OTU19 & 3 & 1 & 0 & 2 & Uncultured bacterium & EF019697 & 94 & $2 \mathrm{~B} 45$ & FM206322 \\
\hline OTU20 & 3 & 1 & 1 & 1 & Paenibacillus ehimensis ${ }^{4}$ & EF025575 & 96 & CB54 & FM206323 \\
\hline OTU21 & 3 & 1 & 1 & 1 & Burkholderia sp. $^{3}$ & EU184087 & 96 & CB17 & FM206324 \\
\hline OTU22 & 3 & 2 & 0 & 1 & Uncultured bacterium & EU133311 & 96 & CB10 & FM206325 \\
\hline OTU23 & 3 & 1 & 0 & 2 & Burkholderia sp. $^{3}$ & AB212228 & 99 & 2B109 & FM206326 \\
\hline OTU24 & 3 & 0 & 2 & 1 & Alicyclobacillus herbarius ${ }^{4}$ & AB042055 & 99 & 1B45 & FM206327 \\
\hline OTU25 & 3 & 3 & 0 & 0 & Sphingoterrabacterium pocheensis ${ }^{7}$ & AB267718 & 97 & CB119 & FM206328 \\
\hline OTU26 & 3 & 1 & 1 & 1 & Bradyrhizobium sp. ${ }^{5}$ & AF216780 & 99 & 2B23 & FM206329 \\
\hline OTU27 & 3 & 0 & 1 & 2 & Uncult. Acidobacteria bacterium ${ }^{9}$ & EU359912 & 98 & $2 \mathrm{~B} 6$ & FM206330 \\
\hline OTU28 & 3 & 1 & 0 & 2 & Sphingomonas oligophenolica ${ }^{5}$ & AB018439 & 99 & 2B55 & FM206331 \\
\hline $\begin{array}{l}\text { Operational tax } \\
\text { Partial sequeno } \\
\text { Betaproteobact } \\
\text { Bacilli. } \\
\text { Alphaproteoba } \\
\text { Actinobacteria } \\
\text { Sphingobacter }\end{array}$ & $\begin{array}{l}\text { xonomic } \\
\text { ces of the } \\
\text { teria. } \\
\text { acteria. } \\
\text { a. } \\
\text { ia. }\end{array}$ & unit & $\begin{array}{l}\text { De } \\
\text { rDN }\end{array}$ & $\begin{array}{l}\text { fines } \\
\text { A ge }\end{array}$ & $\begin{array}{l}\text { different amplified rDNA restriction } \\
\text { ene fragment. }\end{array}$ & analysis (ARDF & RA) patterns. & & \\
\hline
\end{tabular}




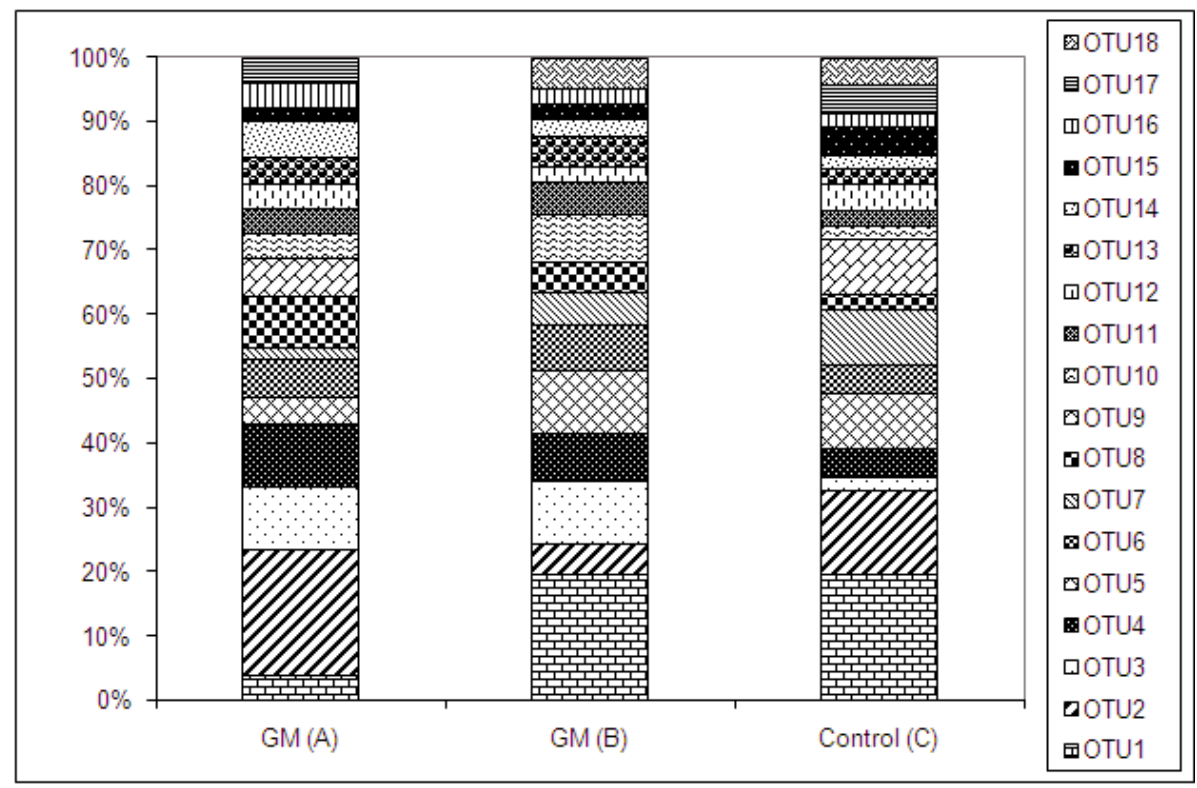

Figure 6. Relative distribution of the most frequent ARDRA pattern of cloned bacterial 16S rDNA fragments derived from the rhizosphere of transgenic (GM treatment A, GM treatment B) and control pine trees $(\mathrm{C})$ from the summer sampling 2005. OTU = operational taxonomic unit.

found OTUs and their distribution between the GM and control treatments.

PCR products obtained with primers NS1/FR1 (fungi) and community DNA from the summer sampling 2005 were cloned and sequenced as described above. Data analysis revealed 92 HinfI patterns (OTUs). Seventythree OTUs were recovered only once. The highest occurrence of these unique OTUs was found for the two GM treatments. The control treatment revealed 12 unique OTUs whereas the two GM treatments revealed 33 (A) and 28 (B) unique OTUs.

The statistical analysis of OTUs revealed significant differences between the two GM treatments A and B for OTU6 $(P=0.0211)$. Based on the OTUs, the diversity indices according to Shannon and Weaver (1949) were calculated. The overall diversity was 3.51 . The highest diversity for fungal clones was found for GM treatment A (3.45) whereas the diversity indices for control and GM treatment B were 2.75 and 3.14, respectively. Inserts from each OTU with at least three clones were selected for sequence analysis. A total of 88 clones were sequenced. Most of the 18S rDNA gene sequences shared $\geqslant 98 \%$ sequence similarity with GenBank entries. Phylogenetic analysis of the different OTUs and their closest relatives in the GenBank database was used to assign clones to a species or phylogenetic group. The results of the sequence analysis of selected clones, their phylogenetic affiliation, and their occurrence among GM and control trees are shown in Table 4. The highest proportion of fungal clones was classified as Basidiomycota $(39 \%)$. Ascomycota represented $23 \%$ of clones in the library, Mucormycotina 5\%, whereas the Zygomycota had low representation $(1 \%)$. Numerous OTUs were recovered only once (32\% of all clones). Forty-two clones grouped into OTU1 and were identified as Bensingtonia yamatoana. The second largest group (OTU2) was identified as Resinicium bicolor. Figure 7 shows the proportional occurrence of the most frequently found OTUs and their distribution between the GM and control treatments.

\section{DISCUSSION}

Understanding of the natural variability and fluctuations in microbial communities associated with trees is a necessary prerequisite to assessment of impacts of GM trees on their associated micro flora. As seen with annual plants, the structure of rhizosphere microbial communities of trees has been shown to vary significantly depending on tree species (Priha et al., 2001), tree health (Filion et al., 2004), or environmental conditions (Graff and Conrad, 2005). The present study investigated the impact of field-grown GM and control $P$. radiata trees on the structure and diversity of rhizosphere microbial communities over a period of two years. To our knowledge there have been no studies in which the microbial communities of trees were monitored over such a long period. Most studies used only a single sampling date 
Table 4. BLAST search results of nucleotide-nucleotide comparison in GenBank and most frequent OTUs associated with the three treatments: non-modified controls (C), and two GM treatments (A and B).

\begin{tabular}{|c|c|c|c|c|c|c|c|c|c|}
\hline \multirow{2}{*}{$\begin{array}{l}\text { Most frequent } \\
\text { OTUs }{ }^{1}\end{array}$} & \multicolumn{4}{|c|}{$\begin{array}{c}\text { Number of occurrence } \\
\text { among treatments }\end{array}$} & \multicolumn{3}{|c|}{ GenBank BLAST analysis } & \multicolumn{2}{|c|}{ Accession no. of clones ${ }^{2}$} \\
\hline & Total & $\mathrm{C}$ & $\mathrm{A}$ & $\mathrm{B}$ & Species ${ }^{\text {Phylogenetic group }}$ & Accession no. & Identity [\%] & Clone & Accession no. \\
\hline \multirow[t]{2}{*}{ OTU1 } & 42 & 18 & 13 & 11 & Bensingtonia yamatoana ${ }^{\mathrm{B}}$ & AF101826 & 98 & $2 \mathrm{~F} 67$ & FM200010 \\
\hline & & & & & Uncultured Boletaceae ${ }^{\mathrm{B}}$ & EF024790 & 99 & CF77 & FM200020 \\
\hline OTU2 & 38 & 11 & 9 & 18 & Resinicium bicolor $^{\mathrm{B}}$ & DQ834914 & 98 & 1F53 & FM200025 \\
\hline \multirow[t]{2}{*}{ OTU3 } & 23 & 7 & 9 & 7 & Chloroscypha enterochroma ${ }^{\mathrm{A}}$ & AY544700 & 98 & CF28 & FM200021 \\
\hline & & & & & Chalara fusidioides ${ }^{\mathrm{A}}$ & AF203463 & 99 & $1 \mathrm{~F} 27$ & FM200009 \\
\hline OTU4 & 19 & 9 & 3 & 7 & Lophium mytilinum $^{\mathrm{A}}$ & DQ678030 & 99 & $2 \mathrm{~F} 11$ & FM200012 \\
\hline \multirow[t]{2}{*}{ OTU5 } & 13 & 5 & 3 & 5 & Trechispora alnicola ${ }^{\mathrm{B}}$ & AY657012 & 97 & $2 \mathrm{~F} 34$ & FM200013 \\
\hline & & & & & Phialiocephala fortinii $^{\mathrm{A}}$ & EU434871 & 99 & 2 F38 & FM200014 \\
\hline OTU6 & 11 & 3 & 7 & 1 & Mortierella parvispora $^{\mathrm{M}}$ & AY129549 & 99 & $1 \mathrm{~F} 42$ & FM200026 \\
\hline OTU7 & 10 & 7 & 3 & 0 & Marasmius alliaceus $^{\mathrm{B}}$ & AY787214 & 98 & $1 \mathrm{~F} 30$ & FM200027 \\
\hline \multirow{2}{*}{ OTU8 } & 9 & 6 & 1 & 2 & Suillus granulatus ${ }^{\mathrm{B}}$ & DQ534691 & 99 & $2 \mathrm{~F} 61$ & FM200015 \\
\hline & & & & & Suillus variegatus ${ }^{\mathrm{B}}$ & DQ534693 & 98 & $1 \mathrm{~F} 94$ & FM200028 \\
\hline \multirow[t]{2}{*}{ OTU9 } & 9 & 4 & 4 & 1 & Penicillium italicum ${ }^{\mathrm{A}}$ & AF548091 & 100 & $1 \mathrm{~F} 86$ & FM200029 \\
\hline & & & & & Penicillium expansum $^{\mathrm{A}}$ & EU590663 & 99 & $2 \mathrm{~F} 119$ & FM200016 \\
\hline OTU10 & 8 & 3 & 4 & 1 & Uncultured Boletaceae ${ }^{\mathrm{B}}$ & EF024981 & 98 & $1 \mathrm{~F} 82$ & FM200030 \\
\hline OTU11 & 4 & 0 & 2 & 2 & Satchmopsis brasiliensis ${ }^{\mathrm{A}}$ & DQ195809 & 99 & $2 \mathrm{~F} 17$ & FM200017 \\
\hline OTU12 & 4 & 1 & 0 & 3 & Umbelopsis nana ${ }^{\mathrm{M}}$ & AF157167 & 99 & $2 \mathrm{~F} 68$ & FM200018 \\
\hline OTU13 & 3 & 3 & 0 & 0 & Zygomycete sp. ${ }^{\mathrm{Z}}$ & EU428773 & 99 & $\mathrm{CF} 47$ & FM200022 \\
\hline \multirow[t]{2}{*}{ OTU14 } & 3 & 0 & 2 & 1 & Elaphocordyceps subsessilis ${ }^{\mathrm{A}}$ & EF469124 & 98 & $2 \mathrm{~F} 12$ & FM200019 \\
\hline & & & & & Oidiodendron tenuissimum ${ }^{\mathrm{A}}$ & AB015787 & 97 & 1F99 & FM200031 \\
\hline \multirow[t]{2}{*}{ OTU15 } & 3 & 1 & 1 & 1 & Heteroconium chaetospira ${ }^{\mathrm{A}}$ & DQ521604 & 99 & $\mathrm{CF} 2$ & FM200023 \\
\hline & & & & & Ascomycete sp. ${ }^{\mathrm{A}}$ & EF638692 & 99 & $1 \mathrm{~F} 62$ & FM200032 \\
\hline OTU16 & 2 & 0 & 1 & 1 & Uncultured Boletaceae $^{\mathrm{B}}$ & EF024619 & 98 & $1 \mathrm{~F} 60$ & FM200033 \\
\hline
\end{tabular}

${ }^{1}$ Operational taxonomic unit. Defines different amplified rDNA restriction analysis (ARDRA) patterns.

${ }^{2}$ Partial sequences of the $18 \mathrm{~S}$ rDNA gene fragment.

A Ascomycota.

B Basidiomycota.

M Mucoromycotina.

${ }^{\mathrm{Z}}$ Zygomycota.

(Andreote et al., 2009; Izumi et al., 2008; Lamarche and Hamelin, 2007; LeBlanc et al., 2007). The results of the present study, in which significant seasonal shifts in various components of the microbial communities occurred, suggests that caution is needed when drawing conclusions about root-associated microbial communities based on results for a single time point.

Seasonal shifts in microbial communities were observed in this study but most dominant populations remained stable during the monitoring period. Smalla et al. (2001) found seasonal shifts in the abundance and composition of the bacterial rhizosphere populations in fieldgrown strawberry, oilseed rape and potato. Lottmann et al. (2000) also observed the appearance of additional dominant DGGE bands in the rhizosphere of field-grown potatoes at the time of flowering. Bacteria are considered as useful bio-indicators in environmental impact studies because they interact continuously with plants and most react quickly to changes in their environment.
The DGGE profiles of 16S rRNA gene fragments obtained with Bacteria-specific primers generate a profile of the most dominant populations (Muyzer et al., 1993; Muyzer and Smalla, 1998), while the nested PCR approach of using taxon-specific primers allows the analysis of minority populations (Heuer et al., 1997, 2001, 2002). The sensitivity of taxon-specific primers has been clearly demonstrated in prior studies of bacterial communities associated with GM and non-GM crop plants (Andreote et al., 2008; O'Callaghan et al., 2008). The statistically significant differences between GM and nonGM treatments detected in this study were always related to only one sampling time (Tab. 1). This finding shows that multiple sampling over a longer period is essential to draw conclusions on the biological relevance of changes in bacterial communities. LeBlanc et al. (2007) found statistically significant differences between the bacterial communities inhabiting the rhizosphere of transgenic white spruce and control trees. Lamarche and Hamelin 


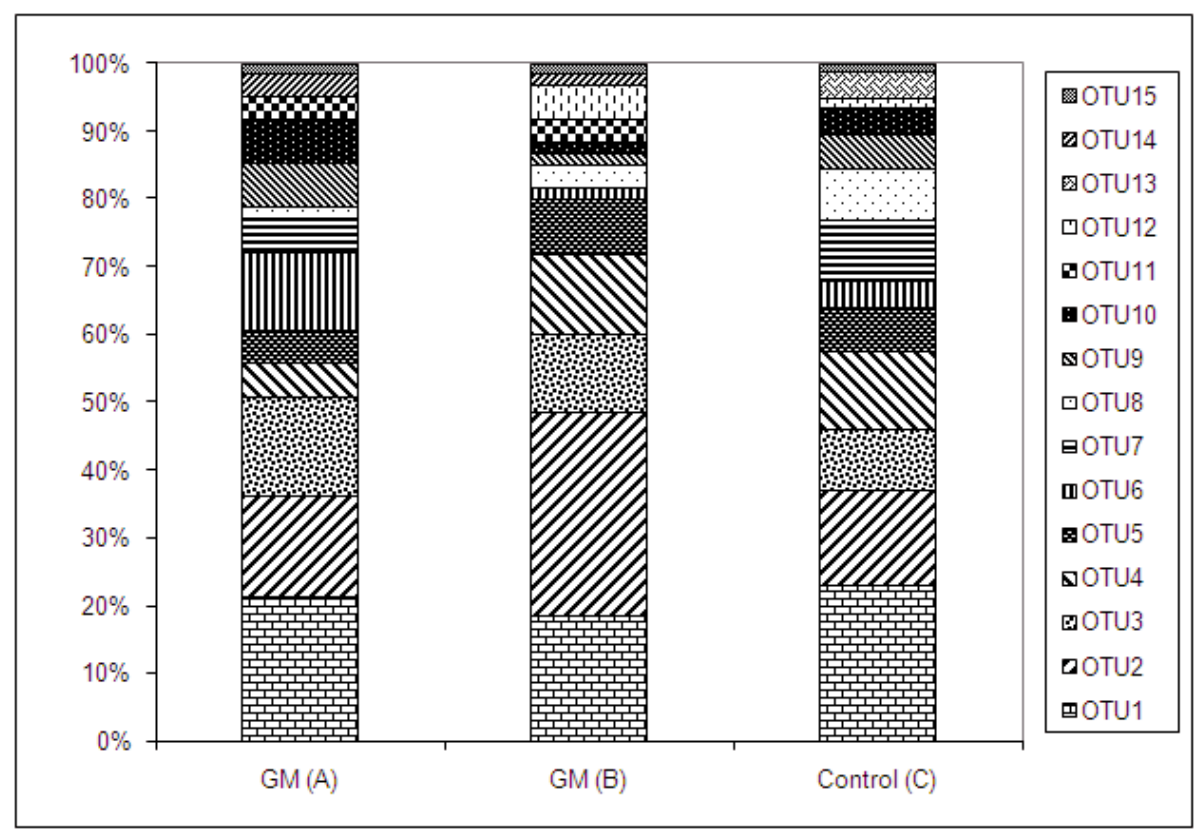

Figure 7. Relative distribution of the most frequent ARDRA pattern of cloned fungal 18S rDNA fragments derived from the rhizosphere of transgenic (GM treatment A, GM treatment B) and control pine trees (C) from the summer sampling 2005. OTU = operational taxonomic unit.

(2007) found no impact on soil nitrogen-fixing bacteria of GM white spruce (Picea glauca) but diazotroph diversity differed between white spruce trees from the plantation site and those from two natural stands near the plantation. Andreote et al. (2009) detected no differences in diversity of Alphaproteobacteria in the rhizosphere of GM and eucalyptus and control trees.

A clone library was generated using rhizosphere DNA collected in summer 2005, to examine rhizosphere bacterial diversity more closely. A summer sample was used because microbial growth and metabolic activity often increase in the spring and summer in conjunction with higher soil temperatures, mobilization of accumulated soil organic matter, and accelerated root growth (Grayston et al., 2001). The bacterial sequences amplified from the rhizosphere of $P$. radiata revealed a very high proportion of populations belonging to the Alpha- and Betaproteobacteria. Alphaproteobacteria is a diverse class of organisms within the phylum Proteobacteria. Environmentally important characteristics such as nitrogen fixation or ammonia oxidation are present in bacteria belonging to this order. Methylobacterium sp., which is ubiquitous in the environment and commonly found in association with plants, was found in association with all three treatments of radiata pine. These results are in accordance with other recent studies of bacterial rhizosphere diversity. Chow et al. (2002) reported that Alpha- and Betaproteobacteria and Acidobacteria dominated the rhizosphere of Pinus contorta grown under forest conditions. The main bacterial groups identified in a study conducted on Black spruce (Pinus mariana) seedlings by Filion et al. (2004) were also Proteobacteria, Acidobacteria and Actinobacteria. In our study Burkholderia spp. was the most frequently detected genus (OTU1, Tab. 3). It was found in all three treatments but showed significant differences between the control treatment $\mathrm{C}$ and $\mathrm{GM}$ treatment $\mathrm{A}$. It is unlikely that this finding is of any biological significance as none of the detected shifts or changes found in this study were persistent. Burkholderia species are common residents of rhizosphere soil and beneficial attributes of some members include nitrogen fixation, plant growth promotion and biological disease control (Opelt et al., 2007; Parke and Gurian-Sherman, 2001). Timonen and Hurek (2006) reported that almost all of the bacteria isolated from the mycorrhizosphere of Pinus sylvestris were identified as Burkholderia spp. Bacteria associated with ectomycorrhiza of Slash pine (Pinus elliotii) were mainly affiliated to species of the genus Burkholderia (Izumi et al., 2008). Kataoka et al. (2008) analysed bacterial communities on Pinus thunbergii root tips and found Burkholderia spp. and Bradyrhizobium spp. were the dominating bacteria. Fluorescent pseudomonads are commonly found in association with plant roots, hence it was surprising that none 
of the clones analysed in our study showed closer similarity to Pseudomonas spp.

To our knowledge this is the first study on the composition and dynamics of both bacterial and fungal (including ectomycorrhizal) communities of GM trees. Like the bacteria, general fungal communities also showed seasonal shifts but communities did not differ significantly between GM and control trees. Fungi are very important members of the microbial communities associated with plant roots and in the present study members of the Basidiomycota and Ascomycota were the most frequently identified fungi of $P$. radiata. The majority of identified OTUs were found in association with all three treatments (Tab. 3). Oliver et al. (2008) found members of the Ascomycota as the dominant group of fungi in the rhizosphere of transgenic polyphenol oxidase-overexpressing and non-GM control aspen but the abundance of the most dominant OTUs was the same in both the transgenic and control clone libraries. In our study the most frequently found OTU was affiliated with the basidiomycetous red yeast Bensingtonia yamatoana, formerly known as Sporobolomyces yamatoanus. This species is extensively distributed throughout the environment. A second phylogentic group associated with OTU1 was affiliated with an uncultured Boletaceae, a family of mushrooms found on every continent except Antarctica. The whiterot basidiomycete Resinicium bicolor (OTU2) is commonly associated with Pinaceae and was found in all three treatments but showed significant differences between the two GM treatments A and B. Our study suggests that such variations are most likely to be temporary. OTU7 was affiliated with the species Marasmius alliaceus, a basidiomycete found in forests growing on rotting wood. This OTU was only found in the control and GM treatment A. Suillus spp. (OTU8) was found in all three treatments and often grows in a mycorrhizal symbiosis with Pinus spp. OTU11 was affiliated with Satchmopsis brasiliensis which is frequently found on leaf litter (Plaingam et al., 2003) but the four clones were only associated with the GM treatments. However, OTUs with a low number of clones, e.g. OTU11, OTU14, or OTU16 showed some variation between transgenic and control pine trees. These variations were statistically not significant and are most likely caused by the discontinuous distribution of fungal populations rather than the influence of genetic modification.

In our study we used rhizosphere soil to amplify ectomycorrhizal fungi associated with GM and non-GM radiata pine. Landeweert et al. (2005) analysed soil and root tips and DGGE results revealed a slightly higher diversity of ectomycorrhizal fungi in soil compared to root tips. No fungal species were exclusively detected on root tips, indicating that the mycelia of most species occur in detectable quantities in soil. In our study ectomy- corrhizal DGGE fingerprints showed a treatment effect at one sampling time (summer 2006) but no differences were detected at any other sampling time. However, seasonal effects were found in both years. Kaldorf et al. (2002) examined mycorrhizal colonisation of GM aspen in a field trial by PCR-RFLP. They found no differences in the mycorrhizal diversity between GM and control trees but observed differences in the abundance and development of one of the four common ectomycorrhizal morphotypes, which was rare and poorly developed on roots from one GM line compared to the parental line. The authors suggested the effect was most likely a somaclonal effect because the formation of this ectomycorrhiza type was not affected in the other GM line. To detect these possible clone specific effects, we have used trees from two different transformation events (GM treatment A and B) in this study. Hampp et al. (1996) showed that transgenic aspen expressing indole acetic acid-biosynthetic genes formed fully developed ectomycorrhiza in vitro. Seppänen et al. (2007) studied the effects of silver birch, genetically modified in lignin biosynthesis, on mycorrhizal fungi. The genetic transformation had a significant influence on root biomass and morphology but the GM lines formed normal ectomycorrhizal associations with the fungus Paxillus involutus.

Sequencing confirmed that all DGGE bands analysed in the ectomycorrhizal community analysis showed high similarities to typical ectomycorrhizal species of the phylum Basidiomycota. Polyporus tuberaster is a white-rot fungus found in Japan, Europe and North America. The order Cantharellales contains mycorrhizal species. The cosmopolitan order Tremellales contains taxa that occur on decaying wood. The family Suillaceae is well known for its symbiosis with pine trees. Because most Suillus ectomycorrhizas occur on Pinus spp. (Chu-Chou and Grace, 1988), and P. radiata is an exotic tree species in the southern hemisphere, it is likely that this fungal species was brought into New Zealand with the introduction of $P$. radiata.

The tight constraints associated with field trials of GM plants in New Zealand meant the trees could only be grown at a single field site, so effects of climatic variability and soil type could not be examined. A potential weakness of the study is that we generated a clone library from only one sampling time. However, the DGGE results from two consecutive years clearly indicated that differences between the GM and control trees were always smaller than seasonal effects.

Whether GM plants have any substantial influence on the soil microbial communities has never been an easy question to answer. Statistically significant changes might be transient and biologically insignificant. Future assessments of impacts of GM plants should focus on functional markers rather than monitoring the structure 
and genetic diversity of microbial communities. New attempts must be made that combine the analysis of phylogenetic, functional and ecological marker genes for the study of soil microbial communities in their environments. Costa et al. (2007) developed a PCR-DGGE system to target Pseudomonas specific gacA gene fragments in environmental DNA. The gacA gene (gacA for global antibiotic and cyanide control) has been proposed to be a reliable phylogenetic marker within the genus Pseudomonas and it might be a suitable target for the simultaneous analysis of Pseudomonas community structure and function in soil.

The main strength of this study was that field-grown trees were monitored for two consecutive years and that both bacterial and fungal communities including ectomycorrhizal fungi were investigated. More long-term studies on field-grown GM trees at different locations are needed to provide the baseline data necessary to relate potential population shifts to natural variability caused by growth stage, soil type, climate, season, or tree species. The long life span of trees makes the evaluation of environmental risks difficult as current regulations in New Zealand restrict field releases of GM trees in both time and space. Full biosafety research on GM trees can only be carried out by permitting long-term and large-scale release of GM trees over a full rotation period.

\section{MATERIALS AND METHODS}

\section{Plant material and experimental site}

Transgenic radiata pines, containing the flowermeristem-identity gene $L E A F Y(L F Y)$ and the nptII selective marker gene, were generated at the Scion Research Centre in Rotorua, New Zealand. Embryogenic tissue of $P$. radiata was genetically transformed using a biolistic technique (Walter et al., 1998). The plasmid vector used for bombardment contained the $n p t I I$ antibiotic selection gene and the $L F Y$ gene, both under control of the CaMV 35S promoter which expresses constitutively in radiata pine. Bombarded tissue was selected on media containing $20 \mathrm{mg} . \mathrm{L}^{-1}$ geneticin and after 5-6 weeks transgenic clones emerged on this medium. Putative transgenic clones were first confirmed by PCR and all positive clones were tested using $n p t I I$ ELISA and Southern hybridisation. Only PCR- and ELISA-positive lines were further propagated and matured to form somatic embryos which were rooted and subsequently planted in soil according to Walter and Grace (2000). All plants were kept in a containment greenhouse from 1998 to 2003. Trees were then transferred to the field trial site in pots and after an adaptation period of five months they were planted into the field, spaced $3 \mathrm{~m}$ apart. The experimental field of approximately $360 \mathrm{~m}^{2}$ was located at the Scion Research Centre in Rotorua, New Zealand. Fifteen trees were included in this study with five trees from each of two independent transformation events (GM treatment $\mathrm{A}$ and $\mathrm{B}$ ) along with five non-transformed control trees $(\mathrm{C})$ of the same genotype. The trial was carried out under the containment conditions specified by the New Zealand Environmental Risk Management Authority (Permit no. GMF99001). The soil type at the site was characterised as slightly gravelly sandy loam containing $13 \%$ clay, $65 \%$ sand, $23 \%$ silt, $9.6 \%$ organic matter with a $\mathrm{pH}$ of 5.3 .

\section{Rhizosphere soil sampling}

From March 2005 to December 2006, root samples with adhering soil were collected from 15 trees ( 5 trees GM treatment A, 5 trees GM treatment B, 5 control trees) quarterly. The roots were dug out along the stem, in order to access fine root segments. Root ends ( $c a .8 \mathrm{~g}$ ) were cut off and placed in sterile plastic bags. Samples were kept at $4{ }^{\circ} \mathrm{C}$ until being processed within $24 \mathrm{~h}$. A total of 120 samples were taken over two consecutive years.

\section{Processing of rhizosphere soil and extraction of whole-community rhizosphere DNA}

Microbial cells were dislodged from soil matrices and pellets were obtained prior to community DNA extraction. Five gram of tree roots with adhering soil were suspended in $25 \mathrm{~mL}$ of distilled water and treated in a Stomacher blender (BagMixer, Interscience, France) for $1 \mathrm{~min}$ at high speed. The rhizosphere soil/water solution was transferred into $50 \mathrm{~mL}$ Falcon tubes. This step was repeated with $20 \mathrm{~mL}$ of distilled water and the combined solutions were centrifuged for $30 \mathrm{~min}$ at $10000 \times \mathrm{g}$. The supernatant was discarded and the pellet dissolved in $4 \mathrm{~mL} 0.85 \% \mathrm{NaCl}$. Aliquots of $2 \mathrm{~mL}$ were centrifuged for $30 \mathrm{~min}$ at $13000 \times \mathrm{g}$. The supernatant was removed with a water-jet vacuum pump and the resulting microbial pellets were kept at $-80{ }^{\circ} \mathrm{C}$. Whole-community DNA was extracted from the microbial pellet using the FastDNA SPIN Kit (BIO 101 Systems, Q-Biogene) according to the manufacturer's protocol. The DNA was kept at $-20^{\circ} \mathrm{C}$ until PCR amplification.

\section{PCR amplification of bacterial 16S rRNA gene fragments}

PCR amplifications were performed with a thermal cycler (Perkin Elmer Gene Amp PCR System or Eppendorf Mastercycler). Prior to DGGE analysis of the bacterial profiles, the V6 to V8 variable regions of the 16S rRNA 
Table 5. Conditions used in this study for DGGE analysis.

\begin{tabular}{lccccc}
\hline PCR products & Fragment length (bp) & Denaturing gradient & \% Acrylamide & Voltage & Run time \\
\hline Bacteria & 433 & $40-65$ & 7 & $90 \mathrm{~V}$ & $16 \mathrm{~h}$ \\
Alpha- and Betaproteobacteria, & 433 & $35-60$ & 7 & $90 \mathrm{~V}$ & $16 \mathrm{~h}$ \\
Actinobacteria & & & & & \\
Fungi (Basidiomycetes) & 800 & $12-38$ & 6 & $90 \mathrm{~V}$ & $16 \mathrm{~h}$ \\
Fungi & 1650 & $8-38$ & 6 & $180 \mathrm{~V}$ & $17 \mathrm{~h}$ \\
\hline
\end{tabular}

genes were amplified by PCR from rhizosphere DNA extracts with the primer pair F968-GC (Nübel et al., 1996) and R1378 (Heuer et al., 1997). All primers used in this study are summarised in Table 5. The reaction mixture $(25 \mu \mathrm{L})$ was composed by $1 \mu \mathrm{L}$ template DNA (whole-community DNA, 1:10 diluted), $2.5 \mu \mathrm{L}$ $10 \mathrm{X}$ PCR buffer IV (ABgene, UK), $0.5 \mu \mathrm{L} 10 \mathrm{mM}$ dNTPs, $1.5 \mu \mathrm{L} 25 \mathrm{mM} \mathrm{MgCl}_{2}, 0.5 \mu \mathrm{L}$ DMSO PCR reagent (Sigma-Aldrich), $0.125 \mu \mathrm{L} \mathrm{T} 4$ gene 32 protein (Roche, Germany), $0.5 \mu \mathrm{L}$ of each primer $(10 \mathrm{mM})$, and $1 \mathrm{U}$ Thermoprime Plus DNA polymerase (ABgene, UK). For all PCR reactions DNase/RNase-free distilled water (Invitrogen) was used. After $5 \mathrm{~min}$ of denaturation at $94{ }^{\circ} \mathrm{C}, 35$ cycles of $30 \mathrm{~s}$ at $94{ }^{\circ} \mathrm{C}, 30 \mathrm{~s}$ at $56{ }^{\circ} \mathrm{C}$ and $1 \mathrm{~min}$ at $72{ }^{\circ} \mathrm{C}$ were carried out. A final extension step of $10 \mathrm{~min}$ at $72{ }^{\circ} \mathrm{C}$ was used to finish the reaction. To emphasize effects of GM trees on microbial communities, the DNA extracts from individual trees were pooled according to the treatment, to give three samples per sampling time and 24 samples for the duration of the monitoring period. The DNA from pooled samples was PCR amplified and subjected to DGGE as described for individual trees. Statistical analysis was only carried out from DGGE data obtained from individual trees.

\section{PCR amplification of taxon-specific 16S rRNA gene fragments}

The amplification of actinobacterial, alpha- and betaproteobacterial 16S rRNA gene fragments was carried out in a nested-PCR approach according to Costa et al. (2005).

\section{PCR amplification of fungal-specific 18S rRNA gene fragments}

Fungal 18S rRNA genes were amplified from wholecommunity DNA using primers FR1-GC and NS1. The PCR mixtures $(25 \mu \mathrm{L})$ contained $1 \mu \mathrm{L}$ template DNA (whole-community DNA, 1:10 diluted), 2.5 $\mu \mathrm{L} 10 \mathrm{X}$ PCR buffer IV (ABgene, UK), $0.5 \mu \mathrm{L} 10 \mathrm{mM}$ dNTPs, $3.75 \mu \mathrm{L} 25 \mathrm{mM} \mathrm{MgCl}_{2}, 0.5 \mu \mathrm{L}$ DMSO PCR reagent (Sigma-Aldrich), $0.125 \mu \mathrm{L}$ T4 gene 32 protein (Roche, Germany), $0.5 \mu \mathrm{L}$ of each primer $(10 \mathrm{mM})$, and $1 \mathrm{U}$
Thermoprime Plus DNA polymerase (ABgene, UK). For all PCR reactions DNase/RNase-free distilled water (Invitrogen) was used. After $5 \mathrm{~min}$ of denaturation at $95^{\circ} \mathrm{C}, 35$ cycles of $30 \mathrm{~s}$ at $95^{\circ} \mathrm{C}, 45 \mathrm{~s}$ at $48^{\circ} \mathrm{C}$ and $3 \mathrm{~min}$ at $72{ }^{\circ} \mathrm{C}$ were carried out. A final extension step of $10 \mathrm{~min}$ at $72{ }^{\circ} \mathrm{C}$ was used to finish the reaction.

\section{PCR amplification of ectomycorrhizal-specific ITS fragments}

Fungal ITS sequences were amplified from wholecommunity DNA using primers ITS1F and ITS4B-GC. The PCR mixtures $(25 \mu \mathrm{L})$ contained $1 \mu \mathrm{L}$ template DNA (whole-community DNA, 1:10 diluted), 2.5 $\mu \mathrm{L} 10 \mathrm{X}$ PCR buffer IV (ABgene, UK), $0.5 \mu \mathrm{L} 10 \mathrm{mM}$ dNTPs, $3.75 \mu \mathrm{L} 25 \mathrm{mM} \mathrm{MgCl}_{2}, 0.5 \mu \mathrm{L}$ DMSO PCR reagent (Sigma-Aldrich), $0.125 \mu \mathrm{L}$ T4 gene 32 protein (Roche, Germany), $0.5 \mu \mathrm{L}$ of each primer $(10 \mathrm{mM})$, and $1 \mathrm{U}$ Thermoprime Plus DNA polymerase (ABgene, UK). After 5 min of denaturation at $94{ }^{\circ} \mathrm{C}, 30$ cycles of $30 \mathrm{~s}$ at $94{ }^{\circ} \mathrm{C}, 1 \mathrm{~min}$ at $61{ }^{\circ} \mathrm{C}$ and $2 \mathrm{~min}$ at $72{ }^{\circ} \mathrm{C}$ were carried out. A final extension step of $10 \mathrm{~min}$ at $72{ }^{\circ} \mathrm{C}$ was used to finish the reaction.

\section{Denaturing gradient gel electrophoresis (DGGE)}

The DCode System (Bio-Rad Inc., Hercules, CA) was used to perform the DGGE analysis. The DGGE protocol was based on the initial protocol of Muyzer et al. (1993) and was performed by using different linear denaturing gradients ( $100 \%$ denaturant contained $7 \mathrm{M}$ urea and $40 \%$ (vol/vol) formamide). The used gradients, voltages, and run times are summarised in Table 5. Aliquots of PCR products $(3-5 \mu \mathrm{L})$ were loaded randomly on the gel. Electrophoresis was carried out in $0.5 \mathrm{X}$ Tris-acetateEDTA buffer at $58{ }^{\circ} \mathrm{C}$. Gels were silver stained according to Heuer et al. (2001) and dried at $60{ }^{\circ} \mathrm{C}$ overnight.

\section{S rRNA gene random clone libraries}

Bacterial 16S rRNA gene fragments of all individual tree samples $(n=15)$ from the first summer sampling (December 2005) were PCR amplified using primers F27 
(Lane, 1991) and R1494. The PCR amplicons of trees of the same treatment $(5 \times$ GM treatment A, $5 \times$ GM treatment $\mathrm{B}, 5 \times$ controls) were combined and separated by electrophoresis in $0.8 \%$ agarose gels. The bands were excised and the DNA purified using the Perfectprep ${ }^{\circledR}$ Gel Cleanup (Eppendorf). Purified fragments were ligated into the pGEM-T Easy vector (Promega) and ligations were transformed into competent Escherichia coli JM109 cells. Dilutions were plated onto LB agar plates with ampicillin ${ }^{100} / \mathrm{X}$-Gal and incubated overnight at $37{ }^{\circ} \mathrm{C}$. For each treatment, 120 white colonies were randomly selected and cultured for $24 \mathrm{~h}$ at $37^{\circ} \mathrm{C}$ on LB agar supplemented with ampicillin and $\mathrm{X}$-Gal. Stable clones were sub cultured overnight in 96 square well storage plates containing $1.5 \mathrm{~mL}$ of LB broth and $100 \mu \mathrm{g} . \mathrm{mL}^{-1}$ ampicillin. Clones were checked for the correct size of inserts after PCR amplification with the primers SP6 and T7 (Promega) according to the manufacturer's instructions. Clones with the correct insert were grown overnight in LB broth supplemented with $100 \mu \mathrm{g} . \mathrm{mL}^{-1}$ ampicillin and $100 \mu \mathrm{L}$ of the culture plus $20 \%$ glycerol was transferred into standard 96 well storage micro plates and stored at $-80{ }^{\circ} \mathrm{C}$.

\section{$18 \mathrm{~S}$ rRNA gene random clone libraries}

Fungal 18S rRNA gene fragments of all individual tree samples $(n=15)$ from sampling 4 (December 2005) were PCR amplified with primers NS1 and FR1. PCR amplicons of trees of the same treatment (5× GM treatment A, $5 \times$ GM treatment B, and $5 \times$ controls) were combined and separated by electrophoresis in $0.8 \%$ agarose gels. The bands were excised and the DNA purified using the Perfectprep ${ }^{\circledR}$ Gel Cleanup (Eppendorf). Purified fragments were ligated into the pGEM-T Easy vector (Promega) and ligations were transformed into competent Escherichia coli JM109 cells and treated as described above.

\section{Amplified ribosomal DNA restriction analysis (ARDRA)}

Inserts of the Bacteria clone library were PCR-amplified by using $2 \mu \mathrm{L}$ of a liquid subculture of clones (LB ${ }^{\mathrm{Ap} 100}$, $37^{\circ} \mathrm{C}$, overnight) as template, $2.5 \mu \mathrm{L} 10 \mathrm{X}$ PCR buffer IV (ABgene, UK), $0.5 \mu \mathrm{L} 10 \mathrm{mM}$ dNTPs, $1.5 \mu \mathrm{L} 25 \mathrm{mM}$ $\mathrm{MgCl}_{2}, 0.5 \mu \mathrm{L}$ of each primer (T7/SP6, Promega), and 1 U Thermoprime Plus DNA polymerase (ABgene, UK). For all PCR reactions DNase/RNase-free distilled water (Invitrogen) was used. The PCR conditions were as follows: initial denaturation $\left(94{ }^{\circ} \mathrm{C}\right.$ for $\left.10 \mathrm{~min}\right)$ followed by 35 cycles of denaturation $\left(94{ }^{\circ} \mathrm{C}\right.$ for $\left.30 \mathrm{~s}\right)$, annealing $\left(56{ }^{\circ} \mathrm{C}\right.$ for $\left.30 \mathrm{~s}\right)$, and extension $\left(72{ }^{\circ} \mathrm{C}\right.$ for $\left.1 \mathrm{~min}\right)$ with a final extension step $\left(72^{\circ} \mathrm{C}\right.$ for $\left.10 \mathrm{~min}\right)$. For the restriction digestion $10 \mu \mathrm{L}$ of positively amplified insert were incubated for $3 \mathrm{~h}$ at $37^{\circ} \mathrm{C}$ with the restriction enzyme Hinf I (New England BioLabs) according to the manufacturer's specifications. The restriction fragments from each clone were separated by electrophoresis in a $2.5 \%$ agarose gel for $100 \mathrm{~min}$ at $80 \mathrm{~V}$ followed by ethidium bromide staining and UV transillumination. All restriction patterns were normalised and compared with the GelCompar II software (Applied Maths, Kortrijk, Belgium). Cluster analysis was performed by the Unweighted Pair Group Method with Arithmetic Mean (UPGMA), and patterns were compared by using the band-based Dice coefficient. The position tolerance and optimization for each set of ARDRA patterns (bacteria, fungi) was automatically calculated by the software. Clones with a $95 \%$ similarity of ARDRA patterns were grouped into the same operational taxonomic unit (OTU). Representatives of each cluster were selected for sequence analysis.

Inserts of the fungal clone library (partial $18 \mathrm{~S}$ rDNA) were PCR-amplified by using $1 \mu \mathrm{L}$ of a liquid subculture of clones ( $\mathrm{LB}^{\mathrm{Ap} 100}, 37^{\circ} \mathrm{C}$, overnight) as template, $2.5 \mu \mathrm{L} 10$ X PCR buffer IV (ABgene, UK), $0.5 \mu \mathrm{L} 10 \mathrm{mM}$ dNTPs, $2.5 \mu \mathrm{L} 25 \mathrm{mM} \mathrm{MgCl} 2,0.5 \mu \mathrm{L}$ of each primer (NS1/FR1), and $1 \mathrm{U}$ Thermoprime Plus DNA polymerase (ABgene, UK). The PCR conditions were as follows: initial denaturation $\left(94{ }^{\circ} \mathrm{C}\right.$ for $\left.10 \mathrm{~min}\right)$ followed by $35 \mathrm{cy}$ cles of denaturation $\left(94{ }^{\circ} \mathrm{C}\right.$ for $\left.30 \mathrm{~s}\right)$, annealing $\left(48{ }^{\circ} \mathrm{C}\right.$ for $45 \mathrm{~s})$, and extension $\left(72{ }^{\circ} \mathrm{C}\right.$ for $\left.2 \mathrm{~min}\right)$ with a final extension step $\left(72{ }^{\circ} \mathrm{C}\right.$ for $\left.8 \mathrm{~min}\right)$. After confirmation of amplicon size using gel electrophoresis, the restriction procedure was applied as described above.

\section{Extraction and cloning of excised DGGE bands}

Characteristic bands from gels displaying ectomycorrhizal fungi were excised and eluted for $24 \mathrm{~h}$ in $20 \mu \mathrm{L}$ of PCR grade water at $4{ }^{\circ} \mathrm{C}$. One micro litre of the resulting suspension was used in a DGGE-PCR to re-amplify the excised ITS fragments. After confirming the correct electrophoretic mobility of the excised band by DGGE, the PCR product (without GC-clamp) was ligated into a pGEM-T Easy vector and transformed into competent E. coli cells as described above. Clones containing inserts that shared the electrophoretic mobility of the original band were selected for ARDRA analysis. HinfI patterns were used to select individual clones. Inserts that showed different ARDRA patterns were submitted for sequencing. 


\section{Sequencing of rDNA gene fragments from bacterial and fungal communities}

DNA sequencing was performed with DNA from clones representing different ARDRA patterns. 16S/18S rDNA fragments were amplified with standard primers T7/SP6 as described for ARDRA. Column purified PCR products were then submitted for sequencing. The sequences were aligned with data from the NCBI GenBank using the megablast algorithm.

All sequenced clones were analysed for the presence of chimeras using the CHIMERA CHECK program from the Ribosomal Database Project (RDP, www.rdp.cme. msu.edu/html). Sequences suspected of being chimeras were not included in further analysis. Nucleotide sequences determined in this study were submitted to the EMBL Nucleotide Sequence Database. The accession numbers are FM200009 to FM200033 (fungal clones) and FM206295 to FM206331 (bacterial clones).

\section{Data analysis}

DGGE gels were scanned with the GS-800 densitometer (BioRad) using Quantity One software (version 4.4.1; Bio-Rad). The intensity and position of bands were saved using the Diversity Database software (version 2.2.0; Bio-Rad). DGGE gels were analysed based on the presence/absence of bands, using principle coordinate analysis (PCO). Lanes were aligned using a Viterbi algorithm for dynamic warping (Glasbey et al., 2005). Peaks were identified by moving a Gaussian model along the series, with the peak position taking all points on the curve, and at each position the amplitude and spread of the peak were estimated. The potential peak positions were then ranked by an index combining amplitude and quality of fit (percentage of variation explained by the model). The top ranked points on this index down to a given cut-off value were taken as the peak positions for each curve. The peaks were clustered into bands using a $k$-means cluster analysis. A similarity matrix between samples was created using the Jaccard similarity measure (Gower, 1985) for the presence and absence of bands. The similarity matrix was reduced to five dimensions using PCO, and linear discriminant analysis was used to evaluate the differences between the treatments. The $95 \%$ confidence regions around the group means depicted in Figures 1, 2, 3 and 5 were produced by the GenStat DISCRIMINATE procedure (Payne et al., 2007). The confidence regions in the graphs cannot be used to determine whether treatment means are significantly different to each other as these relate only to the variation of a single treatment in two dimensions, whereas the Hotelling $T^{2}$-test uses the joint variation of treatments in the full five dimensions of the discriminant space. The confidence regions are presented only to give an indication of the variability of the means. The significance of the treatment differences was assessed using a Hotelling $T^{2}$-test (Hotelling, 1947).

The analysis of ARDRA patterns (operational taxonomic units [OTUs]) used a log-linear modeling approach to compare the OTUs between the three treatments (Statistical software package $\mathrm{R}$, version 2.8.1). Diversity indices $\left(H^{\prime}\right)$ of the bacterial and fungal OTUs were calculated by the Shannon information theory function (Shannon and Weaver, 1949). According to the formula, the coefficient of the number of OTUs and the number of clones indicates the diversity for a treatment. The diversity index $\left(H^{\prime}\right)$ is expressed on an unlimited scale where high numbers represent high diversity.

\section{ACKNOWLEDGEMENTS}

This project was funded by the New Zealand Foundation for Research, Science and Technology (contract numbers C10X0601 and C04X0207). The authors would like to thank Tomoko Pearson for her valuable technical assistance with the field sampling. We acknowledge Anette Becher from AgResearch for her advice and critical reading of the manuscript. We also thank Chikako von Koten for the statistical analysis of ARDRA patterns.

Received October 14, 2009; accepted August 20, 2010.

\section{REFERENCES}

Andreote FD, Mendes R, Dini-Andreote F, Rossetto PB, Labate CA, Pizzirani-Kleiner AA, van Elsas JD, Azevedo JL, Araújo WL (2008) Transgenic tobacco revealing altered bacterial diversity in the rhizosphere during early plant development. Antonie Van Leeuwenhoek 93: 415-424

Andreote FD, Carneiro RT, Salles JF, Marcon J, Labate CA, Azevedo JL, Araújo WL (2009) Culture-independent assessment of Rhizobiales-related Alphaproteobacteria and the diversity of Methylobacterium in the rhizosphere and rhizoplane of transgenic eucalyptus. Microbial Ecol. 57: 82-93

Batista R, Saibo N, Lourenco T, Oliveira MM (2008) Microarray analyses reveal that plant mutagenesis may induce more transcriptome changes than transgene insertion. PNAS 105: $3640-3645$

Bishop-Hurley S, Zabkiewicz RJ, Grace LJ, Gardner RC, Wagner A, Walter C (2001) Conifer genetic engineering: transgenic Pinus radiata (D. Don) and Picea abies (Karst) plants are resistant to the herbicide Buster. Plant Cell Reports 20: $235-243$

Chow ML, Radomski CC, McDermott JM, Davies J, Axelrood PE (2002) Molecular characterization of bacterial diversity in Lodgepole pine (Pinus contorta) rhizosphere soils from British Columbia forest soils differing in disturbance and geographic source. FEMS Microb. Ecol. 42: 347-357 
Chu-Chou M, Grace LJ (1988) Mycorrhizal fungi of Radiata pine in different forests of the North and South Islands in New Zealand. Soil Biol. Biochem. 20: 883-886

Costa R, Götz M, Mrotzek N, Lottmann J, Berg G, Smalla K (2005) Effects of site and plant species on rhizosphere community structure as revealed by molecular analysis of microbial guilds. FEMS Microbiol. Ecol. 56: 236-249

Costa R, Gomes NCM, Krögerrecklenfort E, Opelt K, Berg G, Smalla K (2007) Pseudomonas community structure and antagonistic potential in the rhizosphere: insights gained by combining phylogenetic and functional gene-based analyses. Environ. Microbiol. 9: 2260-2273

Dunfield KE, Germida JJ (2001) Diversity of bacterial communities in the rhizosphere and root interior of field-grown genetically modified Brassica napus. FEMS Microb. Ecol. 82: 1-9

Dunfield KE, Germida JJ (2004) Impact of genetically modified crops on soil and plant associated microbial communities. Environ. Quality 33: 806-815

Filion M, Hamelin RC, Bernier L, St-Arnaud M (2004) Molecular profiling of rhizosphere microbial communities associated with healthy and diseased black spruce (Picea mariana) seedlings grown in a nursery. Appl. Environ. Microbiol. 70: 3541-3551

Gardes M, Bruns TD (1993) ITS primers with enhanced specificity for basidiomycetes - application to the identification of mycorrhizae and rusts. Mol. Ecol. 2: 113-118

Glasbey CA, Vali L, Gustafsson JS (2005) A statistical model for unwarping of 1-D electrophoresis gels. Electrophoresis 26: $4237-4242$

Gomes NCM, Heuer H, Schönfeld J, Costa R, HaglerMendonca L, Smalla K (2001) Bacterial diversity of the rhizosphere of maize (Zea mays) grown in tropical soil studied by temperature gradient gel electrophoresis. Plant Soil 232: $167-180$

Gower JC (1985) Measures of similarity, dissimilarity and distance. In Kotz S, Johnson NL, Read CB, eds, Encyclopaedia of Statistical Sciences 5, Wiley, New York

Grace LJ, Charity JA, Gresham B, Kay N, Walter C (2005) Insect resistant transgenic Pinus radiata. Plant Cell Reports 24: 103-111

Graff A, Conrad R (2005) Impact of flooding on soil bacterial communities associated with poplar (Populus sp.) trees. FEMS Microbiol. Ecol. 53: 401-415

Grayston SJ, Griffith GS, Mawdsley JL, Campbell CD, Bardgett RD (2001) Accounting for variability in soil microbial communities of temperate upland grassland ecosystems. Soil Biol. Biochem. 33: 533-551

Gyamfi S, Pfeifer U, Stierschneider M, Sessitsch A (2002) Effects of transgenic glufosinate-tolerant oilseed rape (Brassica napus) and the associated herbicide application on eubacterial and Pseudomonas communities in the rhizosphere. FEMS Microb. Ecol. 41: 181-190

Hampp R, Ecke M, Schaeffer C, Wallenda T, Wingler A, Kottke I, Sundberg B (1996) Axenic mycorrhization of wild type and transgenic hybrid aspen expressing T-DNA indole acetic acid-biosynthetic genes. Trees - Structure and function 11: $59-64$

Henderson AR, Walter C (2006) Genetic engineering in Conifer Plantation Forestry. Silvae Genetica 55: 253-262

Heuer H, Krsek M, Baker P, Smalla K, Wellington EM (1997) Analysis of actinomycete communities by specific amplification of genes encoding 16S rRNA and gelelectrophoretic separation in denaturing gradients. Appl. Environ. Microbiol. 63: 3233-3241

Heuer H, Wieland G, Schönfeld J, Schönwälder A, Gomes NCM, Smalla K (2001) Bacterial community profiling using DGGE or TGGE analysis. In Rouchelle P, ed, Environmental molecular microbiology: protocols and applications, Horizon Scientific Press, Wymondham, pp 177-190

Heuer H, Kroppenstedt RM, Lottmann J, Berg G, Smalla K (2002) Effects of T4 lysozyme release from transgenic potato roots on bacterial rhizosphere communities are negligible relative to natural factors. Appl. Environ. Microbiol. 68: 13251335

Hotelling H (1947) Multivariate quality control. In Eisenhart C, Hastay MW, Wallis WA, eds, Techniques of Statistical Analysis, McGraw-Hill, New York

Izumi H, Cairney JW, Killham K, Moore E, Alexander IJ, Anderson IC (2008) Bacteria associated with ectomycorrhizas of slash pine (Pinus elliottii) in south-eastern Queensland, Australia. FEMS Microbiol. Letters 282: 196204

Kaldorf M, Fladung M, Muhs HJ, Buscot F (2002) Mycorrhizal colonization of transgenic aspen in a field trial. Planta 214: 653-660

Kataoka R, Taniguchi T, Ooshima H, Futai K (2008) Comparison of the bacterial communities established on the mycorrhizae formed on Pinus thunbergii root tips by eight species of fungi. Plant Soil 304: 267-275

Lamarche J, Hamelin RC (2007) No evidence of an impact on the rhizosphere diazotroph community by the expression of Bacillus thuringiensis Cry1Ab toxin by $\mathrm{Bt}$ white spruce. Appl. Environ. Microbiol. 73: 6577-6583

Landeweert R, Leeflang P, Smit E, Kuyper T (2005) Diversity of an ectomycorrhizal fungal community studied by a root tip and total soil DNA approach. Mycorrhiza 15: 1-6

Lane DJ (1991) 16S/23S rRNA sequencing. In Stackebrandt E, Goodfellow M, eds, Nucleic Acid Techniques in Bacterial Systematics, Hoboken, Wiley, New York, pp 115-175

LeBlanc PM, Hamelin RC, Filion M (2007) Alteration of soil rhizosphere communities following genetic transformation of white spruce. Appl. Environ. Microbiol. 73: 4128-4134

Lottmann J, Heuer H, Smalla K, Berg G (1999) Influence of transgenic T4-lysozyme producing potato plants on potentially beneficial plant-associated bacteria. FEMS Microbiol. Ecol. 29: 365-377

Lottmann J, Heuer H, De Vries J, Mahn A, Düring K, Wackernagel W, Smalla K, Berg G (2000) Establishment of 
introduced antagonistic bacteria in the rhizosphere of transgenic potatoes and their effect on the bacterial community. FEMS Microbiol. Ecol. 33: 41-49

Lukow T, Dunfield PF, Liesack W (2000) Use of T-RFLP technique to assess spatial and temporal changes in the bacterial community structure within an agricultural soil planted with transgenic and non-transgenic potato plants. FEMS Microbiol. Ecol. 32: 241-247

Muyzer G, Smalla K (1998) Application of denaturing gradient gel electrophoresis (DGGE) and temperature gradient gel electrophoresis (TGGE) in microbial ecology. Antonie Van Leeuwenhoek 73: 127-141

Muyzer G, de Waal EC, Uitterlinden AG (1993) Profiling of complex microbial populations by denaturing gradient gel electrophoresis analysis of polymerase chain reactionamplified genes coding for 16S rRNA. Appl. Environ. Microbiol. 59: 695-700

Nübel U, Engelen B, Felske A, Snaidr J, Wieshuber A, Amann RI, Ludwig W, Backhaus H (1996) Sequence heterogeneities of genes encoding 16S rRNAs in Paenibacillus polymyxa detected by temperature gradient gel electrophoresis. J. Bacteriol. 178: 5636-5643

O'Callaghan M, Gerard EM, Bell NL, Waipara NW, Aalders LT, Baird DB, Conner AJ (2008) Microbial and nematode communities associated with potatoes genetically modified to express the antimicrobial peptide magainin and unmodified potato cultivars. Soil Biol. Biochem. 40: 14461459

Oliver KL, Hamelin RC, Hintz WE (2008) Effects of transgenic hybrid aspen overexpressing polyphenol oxidase on rhizosphere diversity. Appl. Envion. Microbiol. 74: 5340-5348

Opelt K, Chobot V, Hadacek F, Schönmann S, Eberl L, Berg G (2007) Investigations of the structure and function of bacterial communities associated with Sphagnum mosses. Environ. Microbiol. 9: 2795-2809

Parke JL, Gurian-Sherman D (2001) Diversity of the Burkholderia cepacia complex and implications for risk assessment of biological control strains. Annu. Rev. Phytopathol. 39: 225-258

Payne RW, Harding SA, Murray DA, Soutar DM, Baird DB, Welham SJ, Kane AF, Gilmour AR, Thompson R, Webster R, Tunnicliffe, Wilson G (2007) The Guide to GenStat Release 10, Part 2: Statistics. VSN International, Hemel Hempstead

Plaingam N, Somrithipol S, Jones EBG (2003) Infundibulomyces: a new genus of coelomycetes from Thailand. Can. J. Bot. 81: 732-737

Priha O, Grayston SJ, Hiukka R, Pennanen T, Smolander A (2001) Microbial community structure and characteristics of the organic matter in soils under Pinus sylvestris, Picea abies and Betula pendula at two forest sites. Biol. Fertil. Soils 33: $17-24$
Seppänen SK, Pasonen HL, Vauramo S, Vahala J, Toikka M, Kilpeläinen I, Setälä H, Teeri TH, Timonen S, Pappinen A (2007) Decomposition of the leaf litter and mycorrhiza forming ability of silver birch with a genetically modified lignin biosynthesis pathway. Appl. Soil Ecol. 36: 100-106

Shannon CE, Weaver W (1949) The mathematical theory of communication. University of Illinois Press, Urbana, pp 3-24

Smalla K, Wieland G, Buchner A, Zock A, Parzy J, Kaiser S, Roskot N, Heuer H, Berg G (2001) Bulk and rhizosphere soil bacterial communities studied by denaturing gradient gel electrophoresis: plant-dependent enrichment and seasonal shifts revealed. Appl. Environ. Microbiol. 67: 4742-4751

Smith SE, Read DJ (1997) Mycorrhizal Symbiosis. Second edition, Academic Press, London

Timonen S, Hurek T (2006) Characterisation of bacterial populations associating with Pinus sylvestris - Suillus bovinus mycorrhizospheres. Can. J. Microbiol. 52: 769-778

Vainio EJ, Hantula J (2000) Direct analysis of woodinhabiting fungi using denaturing gradient gel electrophoresis of amplified ribosomal DNA. Mycol. Res. 104: 927-936

Valenzuela S, Balocchi C, Rodriguez J (2006) Transgenic trees and forest biosafety. Electronic J. Biotechnol. 9: 335339

Van Frankenhuyzen K, Beardmore T (2004) Current status and environmental impact of transgenic forest trees. Can. J. Forest Res. 34: 1163-1180

Wagner A, Ralph J, Akiyama T, Flint H, Phillips L, Torr K, Nanayakkara B, Te Kiri L (2007) Exploring lignification in conifers by silencing hydroxycinnamoyl-CoA:shikimate hydroxycinnamoyltransferase in Pinus radiata. PNAS 104: 11856-11861

Walter C (2004) Genetic engineering in conifer forestry: Technical and social considerations. In Vitro Cell Dev. Biol. Plant 40: 434-441

Walter C, Grace LJ (2000) Genetic engineering of conifers for plantation forestry: Pinus radiata transformation. In Jain SM, Minocha SC, eds, Molecular biology of woody plants, Kluwer, Dordrecht, pp 79-104

Walter C, Grace LJ, Wagner A, White DWR, Walden AR, Donaldson SS, Hinton H, Gardner RC, Smith DR (1998) Stable transformation and regeneration of transgenic plants of Pinus radiata D. Don. Plant Cell Reports 17: 460-468

Weisburg WG, Barns SM, Pelletier DA, Lane DJ (1991) 16S ribosomal DNA amplification for phylogenetic study. J. Bacteriol. 173: 697-703

White TJ, Bruns TD, Lee S, Taylor J (1990) Analysis of phylogenetic relationships by amplification and direct sequencing of ribosomal RNA genes. In Innis MA, Gelfand DH, Sninsky JJ, White TJ, eds, PCR Protocols: a Guide to Methods and Applications, Academic Press, New York, pp 315-322 